\title{
Takstreduksjoner og lønnsforhandlinger
}

Takstbruk som medfører store utgifter for fellesskapet, kan i neste runde innebære at basistakstene blir redusert. I fremtidige lønnsforhandlinger må man prioritere de takstene som muligjgør en forsvarlig legepasient-kontakt fremfor takster som gir kortvarig gevinst for den enkelte spesialist.

Ifølge normaltariffen for 2009 er flere basistakster blitt redusert. Takst $41 \mathrm{a}-\ll$ tillegg for fullstendig undersøkelse hos spesialist» er for eksempel redusert fra $\mathrm{kr} 215$ til kr 156. Begrunnelsen er at beløpet for NAV-utbetalingene er blitt 250 millioner høyere enn forutsatt, noe som gir grunn til ettertanke. Lønnsforhandlingene for privatpraktiserende leger har i alle år tatt sikte på utgiftskompensasjon og på å sikre legene en normal lønnsvekst sammenliknet med andre grupper. Nå er privatpraktiserende leger i den situasjon at de kan øke arbeidstiden og aktiviteten, slik at årsinntekten blir større enn forutsatt av motparten. Resultatet blir en nedjustering i de påfølgende inntektsforhandlinger.

Den gang driftstilskuddet ble innført og satt til $40 \%$ av en normalinntekt, ble resultatet at refusjonene ble redusert tilsvarende og overtidsarbeid mindre lønnsomt. Lærdommen synes å være at alle leger må til- passe seg en normal arbeidstid. Overtid for å redusere ventetider vil ha negativ effekt på inntektsutviklingen over tid.

Et ordtak sier «en god anamnese er halve diagnosen». Det er viktig at Legeforeningen forsøker å bevare takstene for en god anamnese og samtale, slik at legene ikke blir tvunget til hastverksarbeid og til å vri aktiviteten over på en diagnostikk og behandling som verken pasient eller lege har glede av. Problemstillingen kan her anskueliggjøres med følgende eksempel: Har en pasient 30 solare keratoser i ansiktet, vil en behandling med imiquimod eller 5-fluorouracil krem belaste pasienten med to egenandeler $(\mathrm{kr} 295 \times 2)$ og NAV med kr 156. I tillegg kommer utgiften til medikamentet (ca. kr 500 ). Velger legen å bruke fotodynamisk behandling (PDT) må han bekoste $2 \mathrm{~g}$ metylaminolevulinat krem til kr 2 502. Siden utgiften til kremen er vesentlig høyere enn inntekten av taksten for PDT, kr 1 550, kan legen velge å behandle kun én lesjon om gangen, siden taksten ikke kan repeteres i privat praksis. 30 konsultasjoner med PDT-takst 251 belaster NAV med kr 46500 for behandling. Takst 41 a-taksten kommer i tillegg på kr 156 per konsultasjon. Pasienten (eller NAV etter opptjent frikort) må ut med
30 ganger ekstra egenandel ( $\mathrm{kr} 8$ 850). Til sammen blir dette den ikke ubetydelige sum av kr 55506

Ovennevnte viser med all tydelighet at PDT til behandling av multiple solare keratoser kan gi kortvarig gevinst for den enkelte spesialist, men vil føre til store utgifter for fellesskapet. Dette kan igjen føre til ytterligere reduksjon av generelle takster. Den eneste part som profitterer på dette på sikt, er leverandører av medikament og utstyr. De takster det er viktigst å beholde, er de som muliggjør en forsvarlig lege-pasient-kontakt. For å oppnå god behandling og unngå uhell trenger vi god tid med pasienten. Dette må man ha for øye når man neste gang skal i nye lønnsforhandlinger.

\author{
John Sverre Dahle \\ johnsverredahle@sarpsborg.net \\ Dermatologisk poliklinikk \\ Sandesundveien 23 \\ 1424 Sarpsborg \\ Oppgitte interessekonflikter: Ingen
}

Manuskriptet ble mottatt 14.8. 2009 og godkjent 25.1. 2010. Medisinsk redaktør Anne Kveim Lie.

\section{Statlig hvitvasking av legemiddelinformasjon}

Selv om myndighetene hevder at publikum mottar en oppdatert informasjon om legemidler via pakningsvedlegg og preparatomtaler, viser en artikkel i New England Journal of Medicine at informasjon blir borte på veien og at pasienter og leger derfor ikke får den informasjon som er nødvendig for å kunne vurdere nytteverdi og skadevirkninger på en uavhengig og forsvarlig måte (1). Dette problemet er også belyst av redaktøren i $B M J$, Fiona Godlee, som bl.a. skriver at man i flere artikler konkluderer med at beviset for at oseltamivir (Tamiflu) reduserer komplikasjoner hos ellers friske mennesker med pandemisk influensa, er usikker og at vi trenger en radikal endring av reglene for tilgang til rådata (forsøksdata) (2).

Til tross for bl.a. thalidomid-skandalen i 1960-årene og Vioxx-skandalen på 2000tallet har lite eller ingenting skjedd når det gjelder åpenhet om forskningsresultater og mulige interessekonflikter (3-5). Selv ikke rapporter som påpeker sviktende legemiddelkontroll, blir fulgt opp av politikerne. Dette er svært uheldig, ettersom det er viktig at de statlige kontrollorganer for legemidler (og medisinsk utstyr) til enhver tid har den nødvendige kvaliteten og habiliteten (6-7).

Når de samme kontrollorganene som godkjenner legemidler også er ansvarlig for å overvåke sikkerheten for de samme legemidlene (som de allerede har godkjent) etter at de er kommet på markedet, er det kanskje ikke overraskende at de (som regel) med nebb og klør forsvarer det de har gjort. Det er heller ikke overraskende at det er omtrent like vanskelig å få innsyn i såkalte rådata for legemidler som det er å få innsyn i skatteparadiser, hvilket indikerer at helsemyndighetene har valgt å sette industriens profitt foran pasientenes (3). Politikerne bør som et minimum stille krav om åpen deklarasjon av interessekonflikter og åpen tilgang til rådata arkivert i statlige «legemiddelparadiser»».

\section{Svein Reseland}

sreselan@online.no

Hosletoppen 56

1362 Hosle
Oppgitte interessekonflikter: Ingen

\section{Litteratur}

Schwartz LM. Woloshin S. Lost in transmission FDA drug information that never reaches clinicians. N Engl J Med 2009; 361: 1717-20.

2. Godlee F. We want raw data, now. BMJ 2009; 339 : b5405

The tightening grip of big pharma. Lancet 2001 357: 1141.

4. Luepker RV. Drug safety: are we making progress? Arch Intern Med 2010; 170: 202.

5. Maryon-Davis AR. The truth about Tamiflu? Data access is matter of trust. BMJ 2010; 340: c134. www.bmj.com/cgi/content/full/340/jan13_3/c134 (27.1.2010)

6. Woloshin S, Schwartz LM. Bringing the FDA's information to market. Arch Intern Med 2009; 169 1985-87.

7. The U.S. Government Accountability Office (GAO). Drug safety: FDA has begun efforts to enhance postmarket safety, but additional actions are needed. GAO-10-68. www.gao.gov/products/GAO $10-68(27.1 .2010)$

Manuskriptet ble mottatt 27.1. 2010 og godkjent 5.2. 2010. Medisinsk redaktør Anne Kveim Lie. 